\title{
Organization Behavior On Corporate Venture Capital
}

\author{
G.N. Sandhy Widyasthana \\ PT. Metra Digital Investama, \\ Jakarta, Indonesia \\ sandhy.widyasthana@mdi.vc \\ Jann Hidajat Tjakraatmadja \\ School of Business Management ITB \\ Bandung, Indonesia \\ jannhidajat@sbm-itb.ac.id
}

\author{
Dermawan Wibisono \\ School of Business Management ITB \\ Bandung, Indonesia \\ dwibisono@sbm-itb.ac.id \\ Mustika Sufiati Purwanegara \\ School of Business Management ITB \\ Bandung, Indonesia \\ mustika@sbm-itb.ac.id
}

\begin{abstract}
Digital related businesses are growing significantly and globally and, increasing $20 \%$ on average from 2014 to 2020; it is dominated by new rising startups based in Silicon Valley. The financing model implemented by those startups uses Venture Capital (VC) model. There are a lot of numbers of $\mathrm{VC}$ in the world performing a fund rising investing on new startups.Big corporates also participate in investing on those startups using subsidiary company acting as a Corporate Venture Capital (CVC) vehicle that managesthe fund from the parent company. Since 2014, CVC has become the major leading investors in many venture transactions with a big share of venture pie.
\end{abstract}

Venturing is a risky business with a high failure rate and big money involved, but the higher risk at stake will give the higher possibilities of gaining for the company. Big corporates that have strategies on investing by using merger and acquisition models will face difficulties when they invest in this kind of high-risk business. Traditional approaches and thresholds from existing investment models will not match the nature of this business and should be changed by using the venturing scheme. This research explores the change and shift behavior of organization starting from the big corporates to corporate venture capital when they are doing investment using $\mathrm{CVC}$ as a venturing vehicle.

Key Words: Venture Capital, Corporate Venture Capital and Organizational Behavior

\section{INTRODUCTION}

Digital related businesses are growing significantly and globally, increasing an average of $20 \%$ from 2014 to 2020 [6] with consumer digital product as the main segment that has higher growth if whencompared to other segments. Consumer digital products portfolio can be differentiated into softwares and applications based on Internet or cloud network for TV and Video (i.e. YouTube, Google Play etc.), Music (i.e. Pandora, Spotify etc.), Communication (i.e. Skype, WhatsApp etc.), Productivity (i.e. Evernote, Salesforce.com etc.), Collaboration (i.e. Dropbox, Rackspace etc.) and Social Media (i.e. Facebook, Twitter etc.). The top consumer digital products are mainly developed by new rising startups and dominated by startups based on Silicon Valley.

The startups develop their products using financing fromthe third party with Venture Capital (VC) model. VC model is becoming a trend in helping startups to grow. This happens because besides providing funding, it VC also offers mentorship and investor networking to help startups achieve their success. There is a number of VCs in the world performing fund rising for investing on new startups; big corporates also participate in investing on startups using subsidiary companies that act as a Corporate Venture Capital (CVC) vehicle to manage funds from the parent company. Since 2014, CVC has become the major leading investors on many venture transactions in the world with a big share of venture pie. In the future, CVC will still play a critical role in shaping startup business in the world.

Venturing is a risky business with a high failure rate and big money involved. William Hambert, a legendary venture capitalist who made early investment in Apple, Genentech, and Google, said that the possibility of failure rate for venture investing is $90 \%$; it means that there will be only 1 success from each 10 startups invested. Venture capital players like ñ500 Startupò created more moderate calculations for failure rate possibility to around 50-60\%. Even with a low rate of success, venture investing model is still attractive for many VCs/CVCs because the higher risk at stake will give higher possibilities for gain for the company.

Big corporates that have strategies on investing by using merger and acquisition models will face difficulties when they invest in this kind of high-risk business. Traditional approaches and thresholds from existing investment models will not match the nature of this business and should be changed by using the venturing scheme. This research explores the change and shift behavior of organization starting from big corporates to corporate venture capital when they are doing investments using CVC as a venturing vehicle. 
The methodology used in this research was literature review approach to define the significant organizational behavior variables that changed and shifted during the process. The literature review result was verified and analyzed by $\mathrm{CVC}$ experts based on their experience as former big corporate employees and as existing CVC players in Indonesia.

The research was limited in order to focus on organizational behavior changes from corporate operation model to CVC operation model. Further research is needed to explore more detailed behavior on shifting especially for CVC outside Indonesia.

\section{LITERATURE REVIEW}

\section{A. Financing Source}

In creating a new business, entrepreneurs need a funding source to finance their product research \& development and expand their business networks. For an entrepreneur who is wishing to launch or further develop their idea or business, essentially there are five different sources of financing which are available [1]:

1) Self-financing (including personal savings, family and friends);

2) Government or public funding through various programs targeting startups and SMEs,

3) Stock market flotation;

4) Debt financing (bank loans);

5) Equity financing (venture capital, private equity).

Self-financing depends on owners or founders capability to raise funds from their own pocket, startups basically do not have a lot of budget on their bank accounts to fund all company activities, and thus self financing is sometimes suitable only for initial stages of business because later phase of business will need a bigger amount of fund and needs to be supplied by another source of fund.

Government or public funding is targeted at specific startups and SMEôs segments; this condition makes the funds not always available for every startup because startups need to meet certain criteria before they receive the funding.

Stock market financing is only available in the later stage after startup products and businesses are established with certain numbers of customers and entering Initial Public Offering (IPO). Startups in the early stage cannot get this kind of financing, because they do not offer stock to investors yet.

The common option for entrepreneurs to get funding in the initial phase is using debt or equity financing, the characteristic comparison between debts financing through bank loans and equity financing through venture capital as described as follows [5]:

Debt financing through bank loan needs startups assets as a guarantee to protect bank investments, and before releasing the loan to the startup company, the bank also needs a clear business model to make sure that their investment will return and the borrower can start to repay the loan annually as soon as possible based on the terms of agreement on payment between the bank and the startups. This precondition will be difficult to fulfill by startups because usually in the initial phase, startups do not have any asset and only have an idea that is not yet validated. In the initial phase, sometimes startups develop a new product without a clear verified business plan.

With this certain condition, equity financing through venture capital is the best solution for startups to rise a funding because they do not need to have an asset for a bank guarantee and there is no short-term debt payment obligation but compensate it with percentage of ownership stock with longer periodic commitment of return.

Table 1 Debt Financing \& Equity (VC) Financing Comparison [5]

\begin{tabular}{|l|l|l|}
\hline Form of investment & $\begin{array}{l}\text { Debt financing } \\
\text { The company borrows money } \\
\text { which it has to repay later, with } \\
\text { interest }\end{array}$ & $\begin{array}{l}\text { Venture capital tinancing } \\
\text { In return for the funds, the } \\
\text { investor receives a } \\
\text { percentage stake in the } \\
\text { capital of the company } \\
\text { Growth in the value of the } \\
\text { investor's shares }\end{array}$ \\
\hline Investor's source of return & Interest & $\begin{array}{l}\text { An internal rate of return } \\
\text { (IRR) of 35-40\% } \\
\text { Board seals, preferenlial } \\
\text { shareholder rights, put'call } \\
\text { options }\end{array}$ \\
\hline Return on investment & $5-10 \%$ per annum & High to very high \\
\hline Risk & $\begin{array}{l}\text { Morlgage over the assels of the } \\
\text { company }\end{array}$ & Growth potential of company \\
\hline $\begin{array}{l}\text { Considerations for } \\
\text { investor } \\
\text { TIme before Investor } \\
\text { generates income }\end{array}$ & Adequacy of collateral & Typically 2-6 years \\
\hline Means of exit for investor & Loan repayment & IPO or trade sale \\
\hline
\end{tabular}

\section{B. History of Venture Capital}

Venture capital was first established in 1946 after world war II by Karl Compton (MIT President, General Georges F. Doriot (Harvard Business School Professor) and a local business leader using organization named American Research and Development (ARD) [4]. ARD trades a close end fund which trade shares between investors on an exchange like an individual stock [4].

In 1958, Draper, Gaither and Anderson formed the first venture capital limited partnership [4]. This partnership was different from the previous close end funds and was exempt from security regulations, including the exacting disclosure requirements of the investment company act 1940 [4].

During 1960 - 1970 most venture organizations raised money either through closed end fund or Small Business Investment Company (SBIC) and were sponsored by the Federal government to enhance the venture capital industry [4]. In the late 1960s and 1970s most of SBICs collapsed because it was designed poorly by the US government; however, the venture industry increased dramatically in the late 1970 and early 1980 because The US government was permitted to invest the pension funds on venture capital funds followed by the 'prudent man rule [4].

During 1980 - 1990 about 60\% venture funds were distributed to IT industry especially communication and networking, software and information service.The majority 
is based in California for high tech companies like Apple Computer, Cisco System, Genentech, Microsoft, Netscape and Sun Microsystems [4].

\section{Venture Capital Definition \& Roles}

America Venture Capital Association defines VC as a kind of equity capital that plunged into emerging, swift and competitive enterprises by professional financiers. VC financing can be defined as equity investments in closely held private companies with no publicly traded stock intended for a limited period of time [8]. VC is often called ñpatient capitalò as it seeks a return not through immediate and regular payments of principal and interest, but through long-term capital appreciation [5].

Venture capital investors not only provide capital but also offer value-added services to startup in the form of strategic advice (mentoring), introducing alliance networks and facilitating exit strategies [5].

1) Mentoringð VC provide companies with strategic, operational and financial advice [5]. They help startup to form the company as a legal entity, grow an idea to become a product, validate the product to customer and assist with other strategic direction during company operation.

2) Alliances $\delta$ VC can introduce the company to an extensive network of strategic partners, domestically and internationally [5]. VC also can help startup to obtain follow on funding from another partner to expand the business dimension.

3) Facilitate exitठ VC are experienced in the process of preparing a company for an initial public offering (IPO) and can also facilitate a trade sale. [5].

\section{Corporate Venture Capital}

Corporate Venture Capital (CVC) is an activity of equity investment by large corporations in entrepreneurial ventures to pursue both the strategic objectives of their parent company and financial objective [7].

Fig. 1 Venture Capital and Corporate Venture Capital Comparison [11]

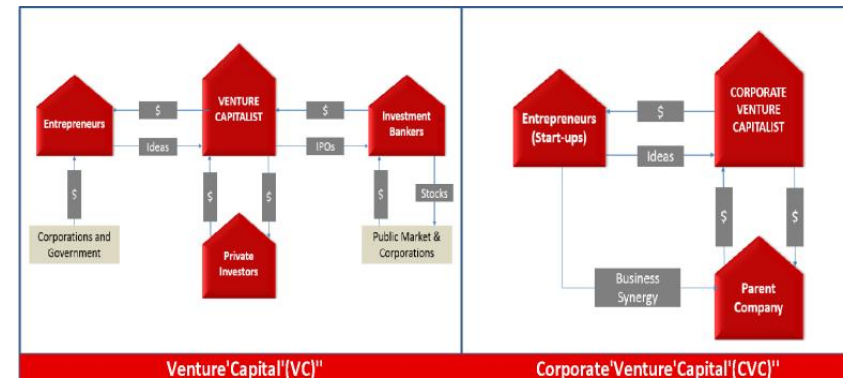

The main differences between $\mathrm{VC}$ and $\mathrm{CVC}$ is from the funding source, CVC funding comes only from its parent company and $\mathrm{VC}$ funding comes from private and public investor. Another different is the objective of venturing, CVC looks for capital gain from startups and also gain from business synergy between startup products and parent company products, while VC mainly targets only for a capital gain from startup companies.

CVC can give benefits to a parent company by providing new opportunities to exploit specific technology areas by accessing complementary technology from startups or by leveraging existing products and technologies in new markets through startups [7]. Many large global companies form $\mathrm{CVC}$ as a part of company long-term business strategy, because they understand that competitors come not only from peer companies but also from new startups with a disruptive business model. Thus, they start to explore and develop a short list of startups that can be targeted as a partner to secure their future businesses.

Examples of CVC from big companies are as follows: Google Ventures (Google), Intel Capital (Intel), Qualcomm Ventures (Qualcomm), GE Ventures (General Electric), Johnson \& Johnson Development Corporation (Johnson \& Johnson) and Samsung Venture Investment (Samsung). Global telecommunication operators also investing in their CVC such as: Innov8 (Singtel), Softbank Capital (Softbank), Docomo Capital (NTT Japan), and Orange Silicon Valley (Orange).

\section{E. Venture Capital Investment Stage}

Investment stage becomes one of the significant variables that should be considered when VC makes an investment. Timing for investment will give different effects to exposure to the risk, the budget needed, product readiness, market readiness and business validation. If $\mathrm{VC}$ decides to invest in the early stage, they may only need a small budget that should be provided for investing, but the risk will be higher because at the early stage the product may not be ready and not commercialized yet. The customers as the target also have not yet validated the capabilities of the product based on their need. If VC decides to invest in the later stage, they need a big amount of budget to invest, but the risk will be lower because the product is already operated in the market and has a number of customers that can be used to validate the business plan.

Table 2 Venture Capital Investment Stage[1]

EVCA classification of investment stages (European Venture Capital Association, 2012)

\begin{tabular}{|c|c|c|}
\hline & Investrnent stago & Aim of investment \\
\hline \multirow{3}{*}{ 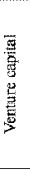 } & Seed & $\begin{array}{l}\text { Financing provided to research, assess and develop an initial concept before a } \\
\text { business has reached the start tup phase. }\end{array}$ \\
\hline & Start-up & $\begin{array}{l}\text { Financing provided to companies for product development and intial marketing. } \\
\text { Companies may be in the proeess of being set up or may have been in business } \\
\text { for a stort time, but not sold their product commercially. }\end{array}$ \\
\hline & Later-stage venture & $\begin{array}{l}\text { Financing provided for the expansion of as operating company, which may or } \\
\text { may not be breaking even or trading profitably. Later-stage verture tends to } \\
\text { finance companios already backed by VCS. }\end{array}$ \\
\hline \multirow{4}{*}{ 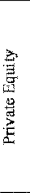 } & Growth & $\begin{array}{l}\text { A type of private equity investmeat - most often a minority investment but } \\
\text { nat necessarily }- \text { in relatively mature companies that are looking for capital to } \\
\text { expand or restructure operations, enter new markets. }\end{array}$ \\
\hline & Resece/turnaround & $\begin{array}{l}\text { Financing made availatle to an existing business which has expetienced troding } \\
\text { difficulities, with a view to te-establishing prosperity. }\end{array}$ \\
\hline & Replacement rapital & $\begin{array}{l}\text { Purchase of a mitority stake of existing shares it a company from another pri- } \\
\text { vate equity firm or from another shareholder or shareholders. }\end{array}$ \\
\hline & Buyout & $\begin{array}{l}\text { Financing provided to accuire a company. It may use a signtificant amount of } \\
\text { borrowed money to meet the cost of alequisition. }\end{array}$ \\
\hline
\end{tabular}




\section{F. Flow of CVC Funding}

CVC get funding from its parent company and it is distributed to startup as equity investment. During the time, startups will give a direct capital gain to the CVC and indirect capital gain to the parent company. Startups also can give a direct contribution to the parent company through their product or market synergy between startups and parent company [3].

Fig. 2 CVC Process Model [3]

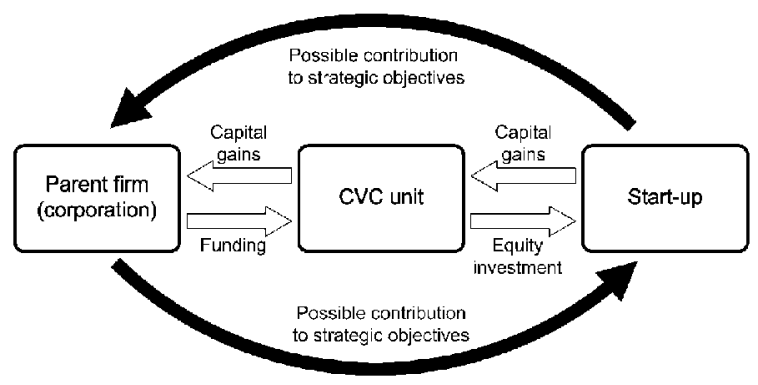

\section{G. Venturing Decision Making Process}

Decision making for investing in CVC is a long and prudent process, and is divided into three stages: screening stage, value added stage and exit stage [5] as shown in figure 3. Decision making at the screening process relates to investing decision whether CVC will invest or not to the startup; the process will include preliminary evaluation, negotiate term sheet with startup and details, due diligence performed by CVC or third party assess or to review startup business appropriateness. The objective of the screening process is to eliminate the risk that will appear during startup company doing business, but even with a thorough screening process, business risk and information asymmetries still remain[1].

Decision making at the value added process depends on CVC objectives to enrich startup capability; at this stage CVC will decide the mentorship programs plan, additional fund budget and strategic alliance for startup business. Decision making at exit stage process will depend on CVC strategies in collecting gain from the existing investment at the startup company; CVC can decide to sell their share at IPO or trade the share with other companies.

\section{THEORY BUILDING}

The development of theory is a central activity in organizational research and the theory can be developed by combining observations from previous literature, common sense and experience [2]. The dimensions implied by the theory definition are indicated by the terms ordered, generic, and range. As generalizations become more hierarchically ordered, behaviors and structures that are the focus of the generalizations become more generic, and the range of specific instances explained becomes broader [10].

Theories and models are two different things; theories almost always incorporate models, but models do not necessarily require theories or a theoretical foundation [9]. This research developed a theory based on a strategic model that should be made aware by big corporations when entering venturing business through CVC. There will be a paradigm shifting in every level of corporate activity and should be well prepared for the success of a business. The model is based on ñThree Level of Strategyò model where each level of strategy will be reviewed with the organization behavior changes from a corporate operation model to CVC operation model.

Fig. 3 Venture Capital Investment Process[5]

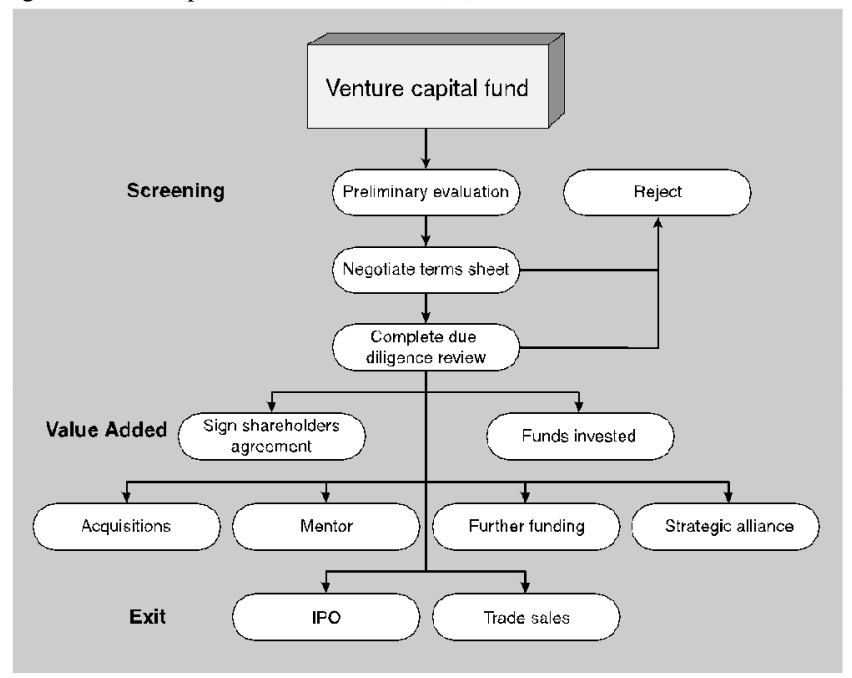

Fig. 4 The Three Levelsof Strategy Change

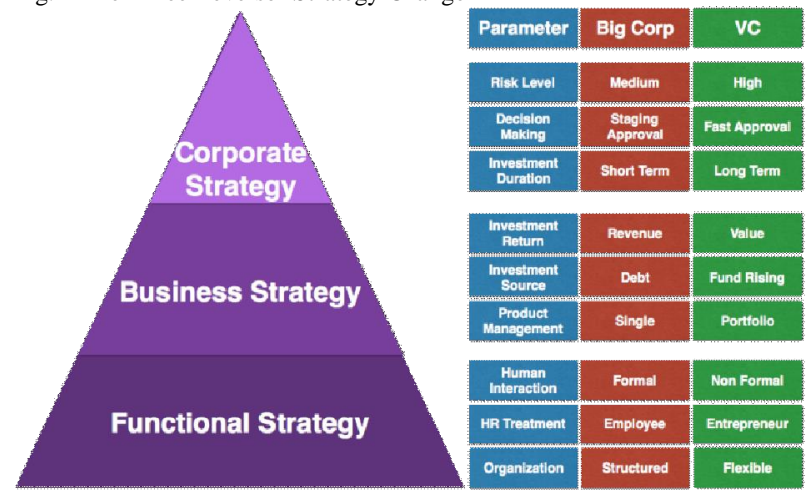

Strategy in business can be split up into three different levels; those are Corporate Strategy level, Business Strategy level, and the Functional Strategy level.The main difference between all of them isdue to their sphere of influence.

\section{A. Corporate Strategy Change}

Corporate strategy is concerned with the overall purpose and scope of the organization to meet stakeholder expectations. This level is heavily influenced by investors and directors in the business and acts to guide strategic decision-making throughout the business. Corporate strategy is often stated explicitly in a ñmission statementò. 
The changes of organizational behavior in the corporate strategy level when the corporate goes into venture business are in the following area:

1) Risk Level; corporates usually have regulations to do a business with moderate or low risk exposure level, corporates always review the business plan and doing a detail due to diligence before deciding to make an investment in order to protect their investment. Venturing business has a nature as business with high-risk exposure level because venture investment at the early stage and at that time the product may not be ready and not commercialized yet. The customers as the target have also not yet validated it and the detail of the business plan is not available yet, so doing venturing business through CVC will shift the risk level that will be faced by the corporates from moderate to high-risk level business.

2) Decision Making; corporate in making a decision should comply with the company regulation, sometimes the decision should follow staging approval up to the board of director and commissioners based on their authority and creates long duration time for decision making. In VC, the decision-making should be decided very fast, because the business trend is changing very fast too and it cannot wait for longer decision. Corporate should adapt their decision making process in CVC to become leaner and faster.

3) Investment Duration; corporates usually make an investment for business that gives return in a short duration for less than 5-year period. VC business by nature is a long duration investment that gives return for more than 5-year period. If corporates want to enter venturing business, they need to change their investment paradigm from a short term to a long-term investment duration.

\section{B. Business Strategy Change}

Business strategy is concerned more with how a business can compete successfully in a particular market, or how to beat the competition. It concerns strategic decisions about choosing products, meeting customer needs, gaining advantage over competitors, exploiting or creating new opportunities, and etc.

The changes of organizational behavior in business strategy level happened when corporates go into venture business in the following area:

1) Investment Return; corporates usually target revenue as a key performance indicator (KPI) for investing business units. It is different from venturing business that does not use revenue as KPI because in the initial stage, startup does not create much cash from their business. The KPI that is used for venturing business in the initial phase is a company valuation and it is measured based on the amount of the funding received by startups during their initial business.
2) Investment Source; corporates in doing investing use self-financing or loan from banking as their financing source and as a return the corporates provide solid business plans and assets for investment assurance. Startups cannot provide guarantee for loan prerequisite, so the investing source for CVC to finance startup uses fund rising and the majority is provided by CVC parent company.

3) Product Management; corporates when perform investing usually focus on a single product or a company that gives a high impact to the corporate business. Venturing business does not have any product with a high impact yet because all of the products are still in the development stage, so investing in $\mathrm{VC}$ should focus on managing the product portfolio that is projected to grow in the future.

\section{Functional Strategy Change}

Functional strategy is concerned with how each part of the business is organized to deliver the corporate and business-unit level on strategic direction. Operational strategy therefore focuses on issues of resources, processes, people and etc.

The changes of organizational behavior in the functional strategy level happened when corporates are going into venture business in following area:

1) Human Interaction; interaction between employees in big corporations use formal communication such as formal letter/email and formal meeting based on the employeeôs position; this is very different with the interaction in CVC that generally use non formal communication like social media chat without any rank barrier. This change should be implemented by corporates when they do VC business, because startups as CVC counter part also uses non-formal interaction on their daily communication.

2) HR Treatment; corporates treat their employees based on the contract between the company and the employees and each party has their own right and obligation that should comply with the corporate regulation. CVC treat their employees as an entrepreneur so they should become creative people without many restrictions for the benefit of the company.

3) Organizational; organization in the corporate is well structured because it should represent all the roles within the company and it is very different from an organization in CVC that is very flexible and depends on the up-to-date situation.

\section{CONCLUSION}

Big corporations which have a plan to enter venture business should be aware about the changing and shifting behavior of the organization and try to adapt the changes for the success of their business. This research helps corporate 
to focus on the area of change by using three levels of strategy approach.

the change implementation will challenge and become a huge effort for the corporate to be faced because it should be implemented in parallel and it will give impact to all levels of corporate strategies. If the corporate has succeeded translating the change to $\mathrm{CVC}$, it will help the CVC to create a good atmosphere for investing in venture business.

The research is limited in order to focus on organizational behavior changes from corporate operation model to CVC operation model. Further research is needed to explore a more detailed shifting behavior, especially for CVC outside Indonesia.

\section{References}

[1] K. Avots, R. Strenga, and A. Paalzow, ñPublic venture capital in Lat viaò, Baltic Journal of Economics 13(1), 2013, 3-30.

[2] K. M. Eisenhardt, ñBuilding Theories from Case Study Research $\square$ ò, The Academy of Management Review, Vol. 14, No. 4, Oct., 1989, pp. 532-550.

[3] H. Ernst, P. Witt, and G. Brachtendorf, ñCorporate venture capital as a strategy for external innovation: an exploratory empirical studyò, R\&D Management, Vol. 35, No. 3, 2005, pp. 233-242.

[4] P. Gompers, J. Lerner, ñThe Venture Capital Revolutionò, The Journal of Economic Perspectives, Spring 2001;15,2.

[5] N. Humphrey, ñWorth The Risk, How To Win Venture Capital Fundingò, Jassa Issue 3 Spring 2000.

[6] A. T. Kearney, ñTelkom Group CSS 2016 ï 2020ò Final BOE Presentation, July 7, 2015.

[7] J. J. Napp, and T. Minshall, ñCorporate Venture Capital Investments For Enhancing Innovation: Challenges And Solutionò, Industrial Research Institute, Inc, 2011.

[8] M. Schefczyk, ñDeterminant of success of German Venture Capital Investmentsò, Interfaces; Sep/Oct 2001; 31, 5; ProQuest pg. 43.

[9] R.A. Swanson, and T. J. Chermack, ñTheory Building in Applied Disciplinesò, Berret-Koehler Publisher Inc, 2013.

[10] K.E. Weick, ñTheory Construction as Disciplined Imaginationò, Academy of Management Review, 1989, Vol. 14, No. 4, 516-531.

[11] B. Zider, ñHow Venture Capital Workò, Harvard Business Review November Ï December 1998 Issue. 